\title{
PENGARUH PEMBELAJARAN INKUIRI TERBIMBING TERHADAP KETERAMPILAN PROSES SAINS SISWA KELAS VII MTS NURUL FALAH JUAI PADA KONSEP SALING KETERGANTUNGAN DALAM EKOSISTEM
}

\author{
Muhammad Ilham \\ Program Studi Pendidikan Biologi STKIP PGRI Banjarmasin \\ Muhammadilhamthegreen@gmail.com
}

\begin{abstract}
ABSTRAK
Proses pembelajaran IPA di MTs Nurul Falah Juai hanya menggunakan metode ceramah, hal ini membuat siswa pasif dalam proses pembelajaran sehingga menyebabkan kurangnya keterampilan proses sains yang dimiliki siswa. Penerapan model pembelajaran inkuiri terbimbing memicu keterampilan proses sains siswa dalam keaktifan belajar melalui beberapa langkah-langkah seperti, merumuskan masalah, merumuskan hipotesis, mengumpulkan data, menganalisis data, dan menyimpulkan. Penelitian ini bertujuan untuk mengetahui pengaruh pembelajaran inkuiri terbimbing terhadap keterampilan proses sains siswa kelas VII MTs Nurul Falah Juai pada konsep saling ketergantungan dalam ekosistem.

Metode penelitian yang digunakan dalam penelitian ini adalah metode penelitian eksperimen dengan desain nonequivalent control group design, dengan populasi semua siswa kelas VII semester II MTs Nurul Falah Juai tahun ajaran 2016/2017 dan sampel kelas VII C sebagai kelas eksperimen, kelas VII B sebagai kelas kontrol. Variabel bebas adalah pembelajaran inkuiri terbimbing dan variabel terikatnya adalah keterampilan proses sains. Teknik pengumpulan data KPS diperoleh melalui indikator KPS yang disusun dalam bentuk pretes dan postes. Teknik analisis data menggunakan uji-t.

Hasil penelitian menunjukan bahwa terdapat pengaruh signifikan penggunaan pembelajaran inkuiri terbimbing terhadap keterampilan proses sains siswa pada konsep saling ketergantungan dalam ekosistem. Hal tersebut dapat dilihat dari hasil perhitungan uji hipotesis dengan mengunakan uji-t pada taraf signifikan $(\alpha=0,05)$ diperoleh hasil $t_{\text {hitung }}>\mathrm{t}_{\text {tabel }}$ atau $5,14>2,03$.
\end{abstract}

Kata kunci : Inkuiri terbimbing, Keterampilan Proses.

\section{PENDAHULUAN}

Pembelajaran IPA merupakan pembelajaran yang menyenangkan bagi siswa, karena pembelajaran IPA biasanya berkaitan langsung dengan alam atau kehidupan sehari-hari. Namun, cara penyempaian guru akan materi pembelajaran hanya terpaku pada buku saja, tanpa mengajak siswa terlibat secara langsung dengan proses pembelajaran. Proses pembelajaran seperti ini membuat siswa cepat bosan dan pasif dalam proses pembelajaran (Midwar, 2015:2).

Hasil wawancara dengan salah seorang guru IPA di kelas VII MTs Nurul Falah Juai, peneliti memperoleh informasi bahwa pembelajaran IPA konsep saling ketergantungan dalam ekosistem pada proses belajarnya guru mengajar dengan metode ceramah dan masih terpaku dengan buku paket. Pembelajaran seperti ini membuat siswa cepat bosan dan pasif dalam proses pembelajaran. Keadaan pembelajaran seperti ini jika dibiarkan terus, maka dapat menyebabkan kurangnya keterampilan proses sains pada siswa. Menurut Dahar dalam Rustaman (2011: 45), keterampilan proses sains adalah kemampuan siswa untuk menerapkan metode ilmiah dalam memahami, mengembangkan dan menemukan ilmu pengetahuan.

Upaya untuk mengatasi kurangnya KPS pada siswa menurut peneliti menggunakan model pembelajaran inkuiri terbimbing. Menurut Sanjaya (2011:196), 
model pembelajaran inkuiri terbimbing menekankan kepada aktivitas siswa secara maksimal untuk mencari dan menemukan ilmu pengetahuan. Dalam proses pembelajaran, peserta didik tidak hanya berperan sebagai penerima pelajaran melalui penjelasan guru secara verbal, tetapi mereka berperan untuk menemukan sendiri inti dari materi pelajaran itu sendiri melalui beberapa langkah-langkah seperti merumuskan masalah, menyusun hipotesis, mengumpulkan data, menganalisis data dan menyimpulkan data.

\section{METODE PENELITIAN}

Metode penelitian yang digunakan dalam penelitian ini adalah metode penelitian eksperimen. Menurut Sugiyono (2011: 72), metode penelitian eksperimen merupakan penelitian yang digunakan untuk mencari pengaruh perlakuan tertentu terhadap yang lain dalam kondisi yang terkendalikan. Desain penelitian yang digunakan adalah nonequivalent control group design. Desain ini mengunakan dua kelas, yaitu kelas eksperimen yang di beri perlakuan pembelajaran inkuiri terbimbing dan kelas control yang diberi perlakuan pembelajaran konvensional. Dua kelas dianggap sama dalam semua aspek yang relevan dan perbedaannya hanya terdapat dalam perlakuan.

Penelitian ini dilaksanakan pada semester II Tahun Pelajaran 2016/2017. Penelitian berlangsung selama satu bulan dari 10 April 2017 sampai 10 Mei 2017. Adapun tempat berlangsungnya penelitian adalah di MTs Nurul Falah Juai Kecamatan Juai Kabupaten Balangan. Populasi dalam penelitian ini adalah semua siswa kelas VII semester II MTs Nurul Falah Juai tahun ajaran 2016/2017. Sampel penelitian adalah kelas VII C sebagai kelas exsperimen dan kelas VII B sebagai kelas kontrol. Pengambilan sampel dilakukan dengan teknik random sampling (sampel acak).

Penelitian ini menggunakan variabel, yaitu variabel bebas dan variabel terikat. Variabel bebas/independent merupakan variabel yang mempengaruhi dalam penelitian ini yaitu pembelajaran inkuiri terbimbing. Sedangkan variabel terikat/dependen merupakan variabel akibat yaitu Keterampilan Proses Sains Siswa.

Teknik pengumpuan data keterampilan proses sains (KPS) siswa diperoleh melalui indikator keterampilan proses sains yang telah disusun dalam bentuk pretes dan postes pada konsep saling ketergantungan dalam ekosistem. Teknik analisis data menggunakan uji-t.

\section{HASIL DAN PEMBAHASAN}

Data hasil penelitian ini adalah data pretes dan postes dari dua kelas, yaitu kelas eksperimen dan kelas kontrol. Pretes dilakukan sebelum proses pembelajaran dengan menggunakan pembelajaran inkuiri terbimbing pada kelas eksperimen dan pembelajaran konvensional pada kelas kontrol. Pretes ini dilakukan untuk mengukur kemampuan awal siswa pada konsep saling ketergantungan dalam ekosistem. Seteah kedua kelas melaksanakan proses pembelajaran dengan perlakuan yang berbeda pada masing-masing kelas. Kemudian dilaksanakan postes yang bertujuan untuk mengukur sejauh mana pengaruh model pembelajaran terhadap keterampilan proses sains (KPS) siswa. 
Hasil pretes yang diperoleh siswa dalam kelas eksperimen dan kelas kontrol dapat dilihat pada tabel 1 berikut.

Tabel 1. Perbandingan Hasil pretes Kelas Eksperimen dan Kelas Kontrol

\begin{tabular}{|c|c|c|}
\hline \multirow{2}{*}{ Data } & \multicolumn{2}{|c|}{ Pretes } \\
\cline { 2 - 3 } & Eksperimen & Kontrol \\
\hline Nilai tertingi & 50 & 50 \\
\hline Nilai terendah & 25 & 25 \\
\hline Mean & 39,5 & 38,94 \\
\hline Median & 40,75 & 40,5 \\
\hline Modus & 45,5 & 45,5 \\
\hline Varians $\left(\mathrm{S}^{2}\right)$ & 62,5 & 71 \\
\hline Standar deviasi $(\mathrm{S})$ & 7,91 & 8,43 \\
\hline
\end{tabular}

Berdasarkan Tabel 4.1 diketahui bahwa, hasil Pretes kelas eksperimen dan kelas kontrol nilai tertinggi 50, nilai terendah kelas eksprimen dan kontrol 25, rata-rata nilai kelas eksperimen 39,5 sedangkan kelas kontrol 38,94, dan standar deviasi kelas eksperimen 7,91 sedangkan standar deviasi kelas kontrol 8,43.

Hasil presentasi pretes pada kelas eksperimen dan kelas kontrol dapat dilihat pada tabel 2

Tabel 2. Presentasi (\%) Ketercapaian Keterampilan Proses Sains Pretes Kelas Eksperimen dan Kelas Kontrol

\begin{tabular}{|c|c|c|c|c|c|}
\hline \multicolumn{5}{|c|}{ Pretes } \\
\cline { 1 - 5 } No & Indikator KPS & Eksperimen & Kategori & kontrol & Kategori \\
\hline 1 & Observasi & $36,11 \%$ & Kurang & $37,50 \%$ & Kurang \\
\hline 2 & Interpretasi & $38,89 \%$ & Kurang & $37,50 \%$ & Kurang \\
\hline 3 & Klasifikasi & $36,11 \%$ & Kurang & $36,11 \%$ & Kurang \\
\hline 4 & Prediksi & $41,64 \%$ & Cukup & $40,28 \%$ & Kurang \\
\hline 5 & Menyimpulkan & $34,72 \%$ & Kurang & $33,33 \%$ & Kurang \\
\hline \multicolumn{7}{c}{ Jumlah } & $187,47 \%$ & \multirow{2}{*}{ Kurang } & $184,72 \%$ & \multirow{2}{*}{ Kurang } \\
\cline { 1 - 2 } & Rata-rata & $37,49 \%$ & & $36,94 \%$ & \\
\hline
\end{tabular}

Berdasarkan tabel 4.2 diketahui bahwa rata-rata keterampilan proses sains pretes pada kelas eksperimen termasuk kategori kurang yaitu 37,49, sedangkan untuk kelas kontrol juga termasuk kategori kurang yaitu 36,94. Keterampilan Proses sains yang paling tinggi pada kelas eksperimen maupun kontrol yaitu prediksi secara berurutan masingmasing 41,64 dan 40,28. Keterampilan Proses sains yang paling rendah yaitu observasi dan klasifikasi sebesar 36,11 pada kelas eksperimen, dan 33,33 untuk keterampilan menyimpulkan pada kelas kontrol.

Hasil postes yang diperoleh siswa dalam kelompok eksperimen dan kelompok kontrol dapat dilihat pada tabel 3 berikut. 
Tabel 3. Perbandingan Hasil Postes Kelas Eksperimen dan Kelas Kontrol

\begin{tabular}{|c|c|c|}
\hline \multirow{2}{*}{ Data } & \multicolumn{2}{|c|}{ Postes } \\
\cline { 2 - 3 } & Eksperimen & Kontrol \\
\hline Nilai Tertingi & 95 & 80 \\
\hline Nilai terendah & 60 & 45 \\
\hline Mean & 83,61 & 65,11 \\
\hline Median & 84 & 65,5 \\
\hline Modus & 84 & 67,25 \\
\hline Varians $\left(\mathrm{S}^{2}\right)$ & 100,72 & 110,81 \\
\hline Standar Deviasi $(\mathrm{S})$ & 10,04 & 10,53 \\
\hline
\end{tabular}

Berdasarkan tabel 3. diketahui bahwa hasil postes kelas eksperimen nilai tertinggi 95 sedangkan kelas kontrol 80, nilai terendah kelas eksprimen 60 sedangkan kelas kontrol 45, rata-rata nilai kelas eksperimen 83,61 sedangkan kelas kontrol 65,11, dan standar deviasi kelas eksperimen 10,04 sedangkan standar deviasi kelas kontrol 10,53.

Hasil presentasi pretes pada kelas eksperimen dan kelas kontrol dapat dilihat pada tabel 4

Tabel 4. Presentasi (\%) Ketercapaian Keterampilan Proses Sains Postes Kelas Eksperimen dan Kelas Kontrol

\begin{tabular}{|c|c|c|c|c|c|}
\hline \multicolumn{6}{|c|}{ Postes } \\
\hline No & Indikator KPS & Eksperimen & Kategori & kontrol & Kategori \\
\hline 1 & Observasi & $81,94 \%$ & Sangat baik & $63,89 \%$ & Baik \\
\hline 2 & Interpretasi & $83,33 \%$ & Sangat baik & $62,50 \%$ & Baik \\
\hline 3 & Klasifikasi & $83,33 \%$ & Sangat baik & $66,67 \%$ & Baik \\
\hline 4 & Prediksi & $83,33 \%$ & Sangat baik & $63,89 \%$ & Baik \\
\hline 5 & Menyimpulkan & $86,11 \%$ & Sangat baik & $63,89 \%$ & Baik \\
\hline & Jumlah & $418,04 \%$ & \multirow{2}{*}{ Sangat baik } & $320,84 \%$ & \multirow{2}{*}{ Baik } \\
\hline & Rata-rata & $83,61 \%$ & & $64,17 \%$ & \\
\hline
\end{tabular}

Berdasarkan tabel 4 diketahui bahwa rata-rata keterampilan proses sains postes pada kelas eksperimen termasuk kategori sangat baik yaitu 83,61, sedangkan untuk kelas kontrol juga termasuk kategori baik yaitu 64,17.

Perhitungan uji prasyarat pengambilan sampel menggunakan data pretes dari kelas eksperimen dan kelas kontrol. Untuk melakukan uji persyarat sampel maka dilakukan uji normalitas dan uji homogenitas. Hasil uji normalitas Pretes kelas eksperimen dapat dilihat pada tabel 5. 
Tabel 5. Hasil Uji Normalitas Pretes Kelas Eksperimen

\begin{tabular}{|c|c|c|c|c|c|}
\hline Kelas & Tes & $\mathbf{N}$ & Lhitung & $\mathbf{L}_{\text {tabel }}$ & Kesimpulan \\
\hline Eksperimen & Pretes & 18 & 0,1864 & 0,2000 & $\begin{array}{c}\text { Berdistribusi } \\
\text { Normal }\end{array}$ \\
\hline
\end{tabular}

Berdasarkan tabel 5 diketehui $\mathrm{L}_{\text {hitung }}<\mathrm{L}_{\text {tabel }}$ atau $0,1864<0,2000$, maka disimpulkan data Pretes kelas eksperimen berdistribusi normal.

Hasil uji normalitas Pretes kelas Kontrol dapat dilihat pada tabel 4.6

Tabel 6. Hasil Uji Normalitas pretes Kelas Kontrol

\begin{tabular}{|c|c|c|c|c|c|}
\hline Kelas & Tes & $\mathbf{N}$ & $\mathbf{L}_{\text {hitung }}$ & $\mathbf{L}_{\text {tabel }}$ & Kesimpulan \\
\hline Kontrol & pretes & 18 & 0,1887 & 0,2000 & $\begin{array}{c}\text { Berdistribusi } \\
\text { Normal }\end{array}$ \\
\hline
\end{tabular}

Berdasarkan tabel 6 diketahui $\mathrm{L}_{\text {hitung }}<\mathrm{L}_{\text {tabel }}$ atau 0,1887 $<0,2000$, maka disimpulkan bahwa data Pretes kelas kontrol berdistribusi normal.

Hasil uji homogenitas kedua kelas dapat dilihat pada tebel 4.7

Tabel 7. Hasil Uji Homogenitas Pretes Kelas Eksperimen dan Kelas Kontrol

\begin{tabular}{|c|c|c|c|c|c|}
\hline Data & $\mathbf{N}$ & $\mathbf{S}^{\mathbf{2}}$ & $\mathbf{F}_{\text {hitung }}$ & $\mathbf{F}_{\text {tabel }}$ & Kesimpulan \\
\hline Kelas Eksperimen & 18 & 62,5 & \multirow{2}{*}{1,14} & 2,27 & $\begin{array}{c}\text { Berdistribusi } \\
\text { Homogen }\end{array}$ \\
\hline Kelas Kontrol & 18 & 71 & & & 27 \\
\hline
\end{tabular}

Berdasarkan tabel 7 diketahui bahwa $F_{\text {hitung }}=1,14$, sedangkan $F_{\text {tabel }}$ dengan $d_{k}$ pembilang $=18-1=17$, dan $d_{k}$ penyebut $=18-1=17($ dengan taraf signifikan $\alpha=0,05)$ adalah 2,27. Karena $F_{\text {hitung }}<F_{\text {tabel }}(1,14<2,27)$, maka disimpulkan bahwa data pretes dari kedua kelas memiliki varians yang sama atau berdistribusi homogen.

Apabila data berdistribusi normal dan homogen maka dilakukan pengujian hipotesis pretes dengan menggunakan rumus uji-t. hasil uji hipotesis pretes dapat dilihat pada tabel 8

Tabel 8. Hasil Uji Hipotesis Pretes Kelas Eksperimen dan Kelas Kontrol

\begin{tabular}{|c|c|c|c|c|c|}
\hline Data & $\mathbf{N}$ & Mean & thitung & ttabel & Kesimpulan \\
\hline $\begin{array}{c}\text { Kelas } \\
\text { eksperimen }\end{array}$ & 18 & 39,5 & \multirow{2}{*}{0,20} & 2,03 & $\begin{array}{c}\text { Ho diterima maka tidak terdapat } \\
\text { perbedaan yang signifikan antara } \\
\text { rata-rata nilai pretes kelas } \\
\text { eksperimen dengan kelas kontrol }\end{array}$ \\
\hline Kelas kontrol & 18 & 38,94 & & & \\
\hline
\end{tabular}

Berdasarkan tabel 8 diketahui bahwa $\mathrm{t}_{\text {hitung }}=0,20$, sedangkan $\mathrm{t}_{\text {tabel }}=2,03$ pada taraf signifikan $\alpha=0,05$ dan derajat kebebasan 34 dari $n_{1}+n_{2}-2$ sedangkan $n_{1}=18$ dan $n_{2}=$ 18. Karena $t_{\text {hitung }}<\mathrm{t}_{\text {tabel }}$ atau $0,20<2,03$, maka dapat disimpulkan bahwa tidak terdapat perbedaan yang signifikan antara rata-rata nilai pretes kelas eksperimen dan kelas kontrol. Kedua kelas telah memenuhi syarat untuk dijadikan sebagai sampel penelitian. Hal tersebut karena kedua kelas memiliki kemampuan awal yang sama. 
Perhitungan uji prasyarat analisis data menggunakan data postes dari kelas eksperimen dan kelas kontrol. Untuk melakukan uji persyarat analisis data maka dilakukan uji normalitas dan uji homogenitas. Hasil uji normalitas postes kelas eksperimen dapat dilihat pada tabel 9.

Tabel 9. Hasil Uji Normalitas Postes Kelas Eksperimen

\begin{tabular}{|c|c|c|c|c|c|}
\hline Kelas & Tes & $\mathbf{N}$ & L $_{\text {hitung }}$ & $\mathbf{L}_{\text {tabel }}$ & Kesimpulan \\
\hline Eksperimen & Postes & 18 & 0,1292 & 0,2000 & $\begin{array}{c}\text { Berdistribusi } \\
\text { Normal }\end{array}$ \\
\hline
\end{tabular}

Berdasarkan tabel 4.9 diketahui $\mathrm{L}_{\text {hitung }}<\mathrm{L}_{\text {tabel }}$ atau $0,1292<0,2000$, maka dapat disimpulkan bahwa data postes kelas eksperimen berdistribusi normal. Hasil uji normalitas postes kelas kontrol dapat dilihat pada tabel 10 .

Tabel 10. Hasil Uji Normalitas Postes Kelas kontrol

\begin{tabular}{|c|c|c|c|c|c|}
\hline Kelas & Tes & $\mathbf{N}$ & Lhiting & $\mathbf{L}_{\text {tabel }}$ & Kesimpulan \\
\hline Kontrol & Postes & 18 & 0,1879 & 0,2000 & $\begin{array}{c}\text { Berdistribusi } \\
\text { Normal }\end{array}$ \\
\hline
\end{tabular}

Berdasarkan tabel 10 diketahui $\mathrm{L}_{\text {hitung }}<\mathrm{L}_{\text {tabel }}$ atau $0,1879<0,200$, maka dapat disimpulkan bahwa data postes kelas kontrol berdistribusi normal. hasil uji homogenitas kedua kelas dapat dilihat pada tebel 11.

Tabel 11. Hasil Uji Homogenitas Postes Kelas Eksperimen dan Kelas Kontrol

\begin{tabular}{|c|c|c|c|c|c|}
\hline Data & $\mathbf{N}$ & $\mathbf{S}^{\mathbf{2}}$ & $\mathbf{F}_{\text {hitung }}$ & $\mathbf{F}_{\text {tabel }}$ & Kesimpulan \\
\hline Kelas Eksperimen & 18 & 100,72 & \multirow{2}{*}{1,10} & 2,27 & $\begin{array}{c}\text { Berdistribusi } \\
\text { Homogen }\end{array}$ \\
\hline Kelas Kontrol & 18 & 110,81 & & \\
\hline
\end{tabular}

Berdasarkan tabel 4.11 diketahui bahwa $F_{h i t u n g}=1,10$, sedangkan $F_{\text {tabel }}$ dengan $d_{k}$ pembilang $=18-1=17$ dan $d_{k}$ penyebut $=18-1=17($ dengan taraf signifikan $\alpha=0,05)$ adalah 2,27. Karena $F_{\text {hitung }}<F_{\text {tabel }}(1,10<2,27)$, maka disimpulkan bahwa data postes dari kedua kelas memiliki varians yang sama atau berdistribusi homogen.

Apabila data berdistribusi normal dan homogen maka dilakukan pengujian hipotesis postes dengan menggunakan rumus uji-t. hasil uji hipotesis postes dapat dilihat pada tabel 12.

Tabel 4.12 Hasil Uji Hipotesis Postes Kelas Eksperimen dan Kelas Kontrol

\begin{tabular}{|c|c|c|c|c|c|}
\hline Data & $\mathbf{N}$ & Mean & $\mathbf{t}_{\text {hitung }}$ & $\mathbf{t}_{\text {tabel }}$ & Kesimpulan \\
\hline $\begin{array}{c}\text { Kelas } \\
\text { eksperimen }\end{array}$ & 18 & 83,61 & 5,14 & 2,03 & $\begin{array}{c}\text { Ho ditolak maka terdapat } \\
\text { perbedaan yang signifikan } \\
\text { antara rata-rata nilai postes kelas } \\
\text { eksperimen dengan kelas kontrol }\end{array}$ \\
\hline Kelas kontrol & 18 & 65,11 & &
\end{tabular}


Berdasarkan tabel 12 diketahui bahwa $t_{\text {hitung }}=5,14$, sedangkan $t_{\text {tabel }}=2,03$ pada taraf signifikan $\alpha=0,05$ dan derajat kebebasan 34 dari $n_{1}+n_{2}-2$ sedangkan $n_{1}=18$ dan $\mathrm{n}_{2}=18$. Karena $t_{\text {hitung }}>\mathrm{t}_{\text {tabel }}$ atau 5,14 $>2,03$, maka dapat disimpulkan bahwa data postes kedua kelas terletak pada daerah penerimaan Ha dan penolakan Ho

Kriteria penerimaan $\mathrm{Ha}$ adalah apabila $t_{\text {hitung }}>\mathrm{t}_{\text {tabel, }}$, karena $\mathrm{t}_{\text {hitung }}$ berada pada daerah penerimaan $\mathrm{Ha}$ sehingga dalam penelitian ini dapat disimpulkan bahwa pembelajaran inkuiri terbimbing berpengaruh terhadap keterampilan proses sains siswa kelas VII MTs Nurul Falah Juai pada konsep saling ketergantungan dalam ekosistem.

Nilai rata-rata pretes kelas eksperimen adalah 39,5. Sedangkan nilai rata-rata pretes kelas kontol 38,94. Berdasarkan data pretes menunjukan rata-rata kedua kelas tidak jauh berbeda, rendahnya nilai rata-rata pretes kedua kelas disebabkan karena materi yang diujikan belum diajarkan kepada siswa, jadi siswa menjawab pertanyaan sesuai pengalaman siswa dalam kehidupan sehari-hari.

Berdasarkan pengujian hipotesis pretes kelas eksperimen dan kelas kontrol dengan uji-t menunjukan bahwa tidak terdapat perbedaan keterampilan proses sains siswa yang signifikan antara kelas eksperimen dan kelas kontrol. Hal tersebut dapat dilihat pada hasil perhitungan $t_{\text {hitung }}<t_{\text {tabel }}$ atau $(0,20<2,03)$. Sehingga kedua kelas (kelas eksperimen dan kelas kontrol) memeliki kemampuan awal yang sama.

Selanjutnya kedua kelas diberi materi pembelajaran tentang saling ketergantungan dalam ekosistem dengan perlakuan yang berbeda. Kelas eksperimen diberi perlakuan menggunakan model pembelajaran inkuiri terbimbing. Sedangkan kelas kontrol diberi perlakuan menggunakan pembelajaran konvensional.

Tes akhir (postes) diujikan setelah pemberian perlakuan pada kedua kelas. Berdasarkan hasil tes keterampilan proses sains dari soal postes diperoleh nilai rata-rata postes kelas eksperimen 83,61. Sedangkan nilai rata-rata kelas kontrol 65,11. Berdasarkan data postes diketahui rata-rata kelas eksperimen lebih tinggi dari pada kelas kontrol $(83,61>65,11)$.

Tingginya rata-rata postes kelas eksperimen sesuai dengan teori bahwa model pembelajaran inkuiri terbimbing menekankan kepada aktivitas siswa secara maksimal untuk mencari dan menemukan ilmu pengetahuan. Dalam proses pembelajaran, peserta didik tidak hanya berperan sebagai penerima pelajaran melalui penjelasan guru secara verbal, tetapi mereka berperan untuk menemukan sendiri inti dari materi pelajaran itu sendiri .Model pembelajaran inkuiri terbimbing memerlukan waktu yang relatif banyak dalam pelaksanaanya, akan tetapi hasil belajar yang dicapai tentunya sebanding dengan waktu yang digunakan. Pengetahuan baru akan melekat lebih lama apabila siswa dilibatkan secara langsung dalam proses pembelajaran (Sanjaya 2011:197).

Indikator keterampilan proses sains yang diukur dalam penelitian ini sebanyak lima indikator. Yaitu, mengamati (observasi), menafsirkan (interpretasi), mengelompokan (klasifikasi), meramalkan (prediksi), dan menyimpulkan. Tabel 13 dibawah ini menunjukan peningkatan persentasi keterampilan proses sains hasil pretes dan postes pada kelompok eksperimen. 
Tabel 13. Peningkatan Keterampilan Proses Sains Kelas Eksperimen

\begin{tabular}{|c|c|c|c|c|}
\hline No & $\begin{array}{c}\text { Keterampilan } \\
\text { Prosses Sains }\end{array}$ & Pretes (\%) & Postes (\%) & Peningkatan(\%) \\
\hline 1 & Observasi & $36,11 \%$ & $81,94 \%$ & $45,83 \%$ \\
\hline 2 & Interpretasi & $38,89 \%$ & $83,33 \%$ & $44,44 \%$ \\
\hline 3 & Klasifikasi & $36,11 \%$ & $83,33 \%$ & $47,22 \%$ \\
\hline 4 & Prediksi & $41,64 \%$ & $83,33 \%$ & $41,69 \%$ \\
\hline 5 & Menyimpulkan & $34,72 \%$ & $86,11 \%$ & $51,39 \%$ \\
\hline \multicolumn{5}{|c|}{ Rata-Rata Peningkatan KPS } \\
\hline
\end{tabular}

Indikator pertama yang diukur adalah keterampilan observasi siswa. Nilai pretes dan postes meningkat dari 36,11\% menjadi 81,94\%, selisihnya sebesar 45,83\%. Adanya peningkatan pada aspek observasi menunjukkan bahwa siswa telah mampu menggunakan sebanyak mungkin inderanya untuk melakukan sebuah pengamatan dan juga mampu menggunakan fakta yang relevan dan memadai dari hasil pengamatan.

Indikator kedua adalah keterampilan proses sains interpretasi (menafsirkan) siswa meningkat dari 38,89\% menjadi $83,33 \%$ sehingga terjadi peningkatan sebesar $44,44 \%$ setelah diberikan perlakuan pembelajaran inkuiri terbimbing. Dari instrumen soal yang mengukur keterampilan ini, siswa diminta membari makna pada gambar konsep saling ketergantungan dalam ekosistem.

Keterampilan proses sains klasifikasi (mengelompokan) siswa meningkat dari $36,11 \%$ menjadi $83,33 \%$ sehingga terjadi peningkatan sebesar $47,22 \%$ setelah diberikan perlakuan pembelajaran inkuiri terbimbing. Hal ini menjukan bahwa siswa telah dapat memilah berbagai objek atau peristiwa berdasarkan persamaan sifat khususnya, sehingga diperoleh kelompok sejenis dari objek atau peristiwa yang dimaksud.

Keteranmpilan proses sans prediksi (meramalkan) nilai pretes dan postes meningkat dari $41,64 \%$ menjadi $83,33 \%$, presentasinya meningkat $41,69 \%$ dari semula. Dalam instrumen soal yang mengukur keterampilan ini, siswa diminta menggambarkan peristiwa yang terjadi apabila matahari tidak ada dalam rantai makanan.

Keterampilan proses sains menyimpulkan siswa meningkat dari $34,72 \%$ menjadi $86,11 \%$ sehingga terjadi peningkatan sebesar $51,39 \%$ setelah diberikan perlakuan pembelajaran inkuiri terbimbing. Hal ini menunjukan bahwa penerapan pembelajaran inkuiri terbimbing memberikan hasil yang positif untuk keterampilan menyimpulkan. Bentuk soal atau tes uraian yang digunakan meminta siswa untuk menyimpulkan gambar tentang konsep saling ketergantungan dalam ekosistem.

Menerapkan pembelajaran inkuiri terbimbing dalam proses pembelajaran membuat siswa menjadi aktif dan siswa dapat membangun sendiri pengetahuan dengan melibatkan secara maksimal seluruh kemampuan siswa untuk mencari dan menyelidiki sesuatu secara sistematis, kritis, logis, dan analisis. Dalam proses pembelajaran inkuiri terbimbing siswa dapat menggunakan pikirannya, siswa juga telibat kerja sama untuk mendiskusikan hasil pengamatan yang telah dilakukan. Dengan demikian pada proses 
pembelajaran guru berperan sebagai fasilitator dan mediator, dan mendorong siswa untuk belajarar mandiri dan terbiasa bekerja ilmiah.

\section{SIMPULAN}

Berdasarkan uraian tersebut dapat disimpulkan bahwa pembelajaran inkuiri terbimbing dalam proses pembelajaran dapat menumbuhkan sikap dan nilai ilmiah didalam pembelajaran IPA. Sehingga pembelajaran IPA menjadi lebih bermakna dan siswa dapat menemukan sendiri pengetahuannya, dan model pembelajaran inkuiri terbimbing memberikan pengaruh yang signifikan terhadap keterampilan proses sains siswa. Sehingga keterampilan proses sains siswa lebih meningkat.

\section{DAFTAR RUJUKAN}

Adetya, Nais Pinta. 2015. pengaruh penerapan model inkuiri terbimbing terhadap hasil belajar dan keterampilan proses sains siswa kelas IX SMA Institut Indonesia pada materi hidrolisis garam. Skripsi diterbitkan. Semarang: Fakultas Matematika dan Ilmu Pengetahuan Alam Universitas Negeri Semarang.

Arikunto, Suharsimi. 2014. Prosedur Penelitian suatu pendekatan praktik. Jakarta: Rineka Cipta.

Cahyo. 2013. Panduan Teori Aplikasi Belajar Mengajar. Bandung: PT Remaja.

Depdiknas. 2010. Perturan Mentri Pendidikan Nasional No 23 Tahun 2006 tentang Standar Kompotensi Lulusan. Dipdiknas. Jakarta.

Dimyati dan Mudjiono. 2013. Belajar dan Pembelajaran. Jakarta Depdiknas.

Hamalik, Oemar. 2010. Proses Belajar Mengajar. Jakarta: Bumi Askara.

Hamdilah, H. 2016. Pengaruh Pendekatan Sainstifik Kurikulum 2013 Terhadap Hasil Belajar Siswa Pada Konsep Interaksi Mahluk Hidup Dengan Lingkungan. Skripsi diterbitkan. Jakarta: Fakultas Ilmu Tarbiyah dan Keguruan Universitas Islam Negeri Syarif Hidayatullah Jakarta.

Kunandar. 2010. Guru Professional Implementasi Kurikulum Tingkat Satuan Pendidikan (KTSP) dan Sukses dalam Sertifikasi Guru. Jakarta : Rajawali Pers.

Midwar, Maulana. 2015. Meningkatkan Keterampilan Proses Sains dan Hasil Belajar Siswa pada Konsep Ekosistem Melalui Model Inkuiri Kelas VII SMPN 2 Batang Alai Selatan Kabupaten Hulu Sungai Tengah. Skripsi tidak diterbitkan. Banjarmasin: STKIP PGRI Banjarmasin.

Rofiyatun. 2016. Meningkatkan Keterampilan Proses Sains pada Konsep Sistem Indra Menggunakan Model Pembelajaran Inkuiri Terbimbing pada Kelas IX IPA SMAN 1 Kuranji. Skripsi tidak diterbitkan. Banjarmasin: STKIP PGRI Banjarmasin.

Rusdi, Lamhani. 2016. Penerapan Model Inkuiri Terbimbing Dalam Meningkatkan Keterampilan Proses Sains (KPS) dan hasil Belajar Peserta Didik pada Konsep 
Saling Ketergantungan Dalam Ekosistem di Kelas VII B SMP Negeri 2 Batang Alai Utara. Skripsi tidak diterbitkan. Banjarmasin: STKIP PGRI.

Rustaman. 2011.Stretegi belajar Mengajar Biologi. Malang: UM Perss.

Sanjaya W. 2011. Strategi Pembelajaran Beroientasi Standar Proses Pendidikan. Jakarta : Kencana Prenada Media Group.

Sofiani, Erlina. 2011. pengaruh model inkuiri terbimbing (Guided inquiry) terhadap hasil belajar fisika siswa pada konsep listrik dinamis. Skripsi diterbitkan. Jakarta: Fakultas Ilmu Tarbiyah dan Keguruan Universitas Islam Negeri Syarif Hidayatullah Jakarta.

Sugiyono. 2011. Metode Penelitian Kuantitatif, Kualitatif, dan R\&D.. Bandung: Alfabeta.

Susanti, Wulan. 2014. Pengaruh Model Inkuiri Terbimbing Terhadap Keterampilan Proses Sains Siswa Pada Materi Laju reaksi. Skripsi diterbitkan. Jakarta: Fakultas Ilmu Tarbiyah dan Keguruan Universitas Islam Negeri Jakarta.

UU, No 20. 2003. Sistem Pendidikan Nasional.

Zubaidah, Siti, Mahanal, Lia, dan Sigit Darsono. 2014. Buku Guru Ilmu Pengetahuan Alam. Jakarta: Kementerian Agama Pendidikan dan Kebudayaan. 